формування основ педагогічної майстерності майбутнього вчителя початкових класів : [монографія]/ Н. В. Теличко. - Київ: Кондор, 2014. - 522 с. 10. Ушинський К. Д. Людина як предмет виховання. Спроба педагогічної антропології / Вибр. тв.: В 2 т. - К.: Рад. шк., 1983. - Т.1. - С. 192-472. 11. Философский энциклопедический словарь / Е.Ф. Губский, Г. В. Кораблева, В. А. Лутченко. - М. : ИНФРА-М，2007. - 576 с. 12. Шулдик Г. О. Педагогічна практика: [навч. посіб.для студ.пед. вузів] / Г. О. Шулдик, В. І. Шулдик. - К. : Науковий світ, 2000. - 143 с. 13. Ягупов В. В. Педагогіка : [навч. посіб.] / В. В. Ягупов. - К. : Либідь, 2003. - 560 с.

УДК $371.15+355.23$

Василь Георгієв

\title{
РОЛЬ НАСТАВНИЦТВА У ФОРМУВАННІ ОСОБИСТІСНИХ I ПРОФЕСІЙНИХ ЯКОСТЕЙ МАЙБУТНІХ ОФІЦЕРІВ ВИСОКОМОБІЛЬНИХ ДЕСАНТНИХ ВІЙСЬК
}

Георгієв В. М. Роль наставництва у формуванні особистісних і професійних якостей майбутніх офіцерів Високомобільних десантних військ.

У статті аналізується проблема педагогічного наставництва в сучасній системі освіти, розглядаються специфіка та основні задачі наставництва у військових ВНЗ загалом та під час роботи з майбутніми офіцерами Високомобільних десантних військ зокрема. Автор визначає особистісні та професійні якості офіцера-наставника, основні принципи його діяльності.

Ключові слова: педагогічне наставництво, професійне становлення, військовий вищий навчальний заклад, офіцер-наставник, майбутні офіцери, Високомобільні десантні війська.

Георгиев В. М. Роль наставничества в формировании личностных и профессиональных качеств будущих офицеров Высокомобильных десантних войск.

В статье анализируется проблема педагогического наставничества в современной системе образования, рассматриваются специфика и основные задачи наставничества в военных вузах вобщем и во время работы с будущими офицерами Высокомобильных десантных войск в частности. Автор определяет личностные и профессиональные качества офицера-наставника, основные принципы его деятельности.

Ключевые слова: педагогическое наставничество, профессиональное становление, военное высшее учебное заведение, офицер-наставник, будущие офицеры, Высокомобильные десантные войска.

Georgiev V. M. The role of mentoring in the formation of personal and professional qualities of the future officers of the Highly mobile airborne troops.

This article analyzes the problem of pedagogical mentoring in modern education. The main purpose of mentoring in the military schools, as the author considers, is the formation of cadets' positive emotional attitude towards their future profession. The main principles of mentoring activities are: voluntary and purposefulness; respect for the cadet's personality; benevolence; own example; and orientation of planned activities on education and professional development of the future airborne officers.

Key words: pedagogical mentoring, professional development, military higher educational institution, officer-instructor, future officers, Highly mobile airborne troops. 
Останнім часом відбувається ускладнення діяльності офіцерів Високомобільних десантних військ, підвищуються вимоги до їх моральних, бойових та психологічних якостей, що зумовило зростання ролі педагогічного наставництва у формуванні особистісних і професійних якостей майбутніх офіцерів ВДВ.

Проблему наставництва в педагогіці розглядали І. Барабашова, Л. Виготський, I. Воронін, Л. Жиліна, Н. Івченко, І. Кон, С. Кузнецов, А. Макаренко, Л. Фоміна. Ці та інші автори під наставництвом розуміють систему соціально-педагогічних упливів більш досвідчених спеціалістів на почуття, свідомість та волю учнів задля формування в них широкого світогляду, виховання стійкої життєвої позиції та бажання оволодіти професією.

У військовій педагогіці проблему професійного становлення розглядали В. Артамонов, І. Альохін, О. Барабанщиков, В. Давидов, Н. Зеленська, С. Муцинов, В. Новіков, В. Самойлов, Л. Снігур, О. Хижняк та ін. Водночас спеціальних досліджень упливу офіцера - наставника на формування особистості курсанта обмаль (С. Демочкін, Н. Котов, В. Коровін, І. Пугін, С. Товт та ін.). На жаль, дослідження впливу наставництва на формування особистісних та професійних якостей майбутніх офіцерів Високомобільних десантних військ в Україні відсутні.

Mema cmammi- проаналізувати особливості педагогічного наставництва у військових ВНЗ та визначити роль офіцера-наставника у формуванні професійних та особистісних якостей майбутніх офіцерів Високомобільних десантних військ.

Феномен педагогічного наставництва (С. Демочкін, В. Коровін та ін.) розглядається як процес, що складається 3 багатьох компонентів: дидактичних, виховних і соціально-педагогічних взаємодій, який відбувається між вихователем та вихованцем і спрямований на розвиток особистості вихованця.

Педагогічне наставництво у військовому ВНЗ $є$ складником взаємодії командирів, педагогів та курсантів. При цьому наставник повинен мати певний досвід, ділитися своїми знаннями 3 курсантами, створювати атмосферу взаємної поваги та довіри.

Основною метою наставництва, на думку С. Демочкіна, є навчання та розвиток здібності курсанта керувати траєкторією свого професійного становлення [2].

С. Товт зазначає, що професійне становлення курсантів військового ВН3 - це процес формування особистісно-професійної позиції індивіда з урахуванням усієї різноманітності суб'єктивних і об'єктивних чинників. При цьому особистіснопрофесійна позиція розуміється автором як система домінуючих ціннісно-змістових ставлень спеціаліста до соціокультурного оточення, самого себе та своєї діяльності [5].

В. Коровін, досліджуючи суб'єктивні та об'єктивні чинники в навчальному середовищі військового ВНЗ, виокремлює матеріальний i нематеріальний компоненти. Матеріальний компонент визначає ступінь забезпечення навчального процесу відповідно до навчальних планів за спеціальностями підготовки військових спеціалістів. До нього відноситься навчально-матеріальна база військового ВНЗ. Нематеріальний компонент втілюється у виховному середовищі ВВНЗ. Його основним елементом є духовне і моральне виховання та розвиток курсантів [4].

Виховна робота у військовому ВНЗ становить організований, цілеспрямований та систематичний процес взаємодії та впливу всіх категорій посадових службовців, професорсько-викладацького складу на свідомість, почуття, волю курсантів задля формування в них високих професійних якостей відповідно до вимог, що висуваються до професійної діяльності військових спеціалістів [3]. 
Працюючи у військовому ВНЗ, ми можемо стверджувати, що основною метою виховання у такому закладі є формування та розвиток високоморальної особистості, офіцера-патріота своєї Вітчизни, спеціаліста-професіонала.

Відсутність наставництва негативно впливає на професійне становлення майбутнього спеціаліста. Водночас О. Гришаєв, М. Щербакова вказують на те, що в навчальному процесі ВНЗ необхідно дотримуватися низки вимог, які забезпечують ефективність роботи наставника-куратора:

1. Надійне діагностування професійно-особистісного розвитку, що охоплює всіх студентів, систематичний моніторинг рівня сформованості найважливіших особистісних та професійних якостей майбутніх спеціалістів.

2. Реальна диференціація та індивідуалізація професійного виховання, заснована на результатах моніторингу професійно-особистісного розвитку студентів.

3. Куратор повинен бути ознайомленим 3 віковими психофізіологічними особливостями студентів, особливостями їх мотиваційної сфери, психологією міжособистісної взаємодії і психологією навчальної групи.

4. Майбутнім спеціалістам повинні бути висунені еталони, зразки, які визначають вимоги до особистості як представника своєї професії.

5. Повинні бути забезпечені реальні умови самооцінки для порівняння себе 3 іншими, формування на цій основі власних перспектив професійного та особистісного зростання.

6. Студент повинен бачити та розуміти динаміку позитивного та стійкого професійно-особистісного розвитку, сам повинен оцінювати, наскільки він наблизився до заданого ним самим еталону.

7. Повинна бути запропонована низка варіантів суспільно корисної професійно зорієнтованої практичної діяльності [1].

Уважаємо, що визначені вимоги будуть доцільними і для військового ВНЗ.

Н. Зеленська у дисертаційній роботі зазначає, що у військовому ВНЗ у межах педагогічного наставництва необхідно реалізовувати такі завдання:

- стимулювання пізнавальної активності майбутніх військових спеціалістів, формування в них необхідних якостей особистості, поведінки у професійній діяльності;

- формування високої духовності майбутніх офіцерів;

- забезпечення взаємозв'язку виховного процесу 3 навчальною та науковою роботою;

- створення умов для формування професійних цінностей та військової культури;

- надання допомоги курсантам у розкритті їх власних можливостей, сприяння їх самовизначенню, самоствердженню та самореалізації в майбутній військовопрофесійній діяльності;

- орієнтування керівництва i професорсько-викладацького складу ВВНЗ на перехід від розрізненості і масовості виховних заходів до комплексного підходу у вихованні курсантів, повсякденній та індивідуальній роботі з ними;

- формування професійної компетентності, уміння виробляти власну стратегію і тактику професійної діяльності;

- виховання самовідданості та здатності до подолання труднощів і поневірянь;

- формування почуття власної професійної гідності, прихильності до високих понять: Вітчизна, обов'язок, честь, культура, віра, любов, істина [3, с. 219-220].

У центрі уваги офіцера-наставника повинен бути різнобічний розвиток майбутнього офіцера, його здібностей та інтересів. У зв'язку з цим все більшого значення набуває орієнтація навчально-виховного процесу військових ВНЗ на 
формування активної та творчої особистості, професійне становлення майбутнього офіцера.

Професійне становлення майбутнього офіцера відбувається протягом усього перебування у військовому ВНЗ. На думку С. Демочкіна, професійне становлення - це формування професійної спрямованості, компетентності, соціально значущих і професійно важливих якостей та їх інтеграція, пошук оптимальних засобів якісного i творчого виконання професійної діяльності відповідно до індивідуальнопсихологічних особливостей особистості. Професійне становлення передбачає змістово-операційний, мотиваційний i емоційно-вольовий компоненти, які взаємопов'язані і знаходяться в органічній єдності [2, с. 9].

У процесі професійного становлення, як доводять дослідження С. Демочкіна, виникають суперечності між наявними якостями особистості і об'єктивними вимогами професійної діяльності. Тому офіцер-наставник повинен уміти використовувати розгорнуті в часі прийоми соціального впливу на особистість, залучати курсантів до різноманітних професійно значущих видів діяльності (пізнавальної, навчально-професійної тощо) задля формування системи професійно важливих знань, умінь, якостей, форм поведінки та індивідуальних способів виконання професійної діяльності [2].

Отже, педагогічне наставництво у специфічних умовах військового ВН3 спрямоване на розвиток особистості майбутнього офіцера та формування його професійного становлення під час навчально-виховного процесу. Офіцер-наставник також повинен впливати на формування самосвідомості, самооцінки, самодисципліни та бажання курсантів удосконалювати власні якості відповідно до професійних вимог.

У формуванні системи наставництва ВВНЗ, ураховуючи власний досвід роботи, а також спираючись на праці Г. Андреєвої, Ю. Бабанського, Л. Виготського, I. Зимньої, А. Макаренка та інших, виокремлюємо такі основні принципи:

- добровільність та цілеспрямованість роботи офіцера-наставника;

- морально-психологічна сумісність офіцера-наставника та курсанта;

- особистий приклад офіцера-наставника;

- доброзичливість та взаємоповага;

- повага до думки курсантів;

- спрямованість планової діяльності офіцера-наставника на виховання та професійне становлення майбутніх офіцерів Високомобільних десантних військ.

Основне призначення наставництва - формувати в курсантів позитивне, емоційно забарвлене ставлення до майбутньої професії, захопленість і активне прагнення оволодіти нею, стійку внутрішню готовність до подолання труднощів, пов'язаних з професійною діяльністю офіцера Високомобільних десантних військ у мирний та військовий час, відповідну емоційно-вольову стійкість.

До завдань педагогічного наставництва, виходячи із власного досвіду роботи у військовому ВНЗ, також відносимо:

- прискорення в курсантів першого року навчання адаптації до специфічних умов військових ВНЗ;

- спрямування курсантів на розвиток необхідних для майбутньої професії особистісних якостей;

- поліпшення процесу професійного становлення майбутнього офіцера Високомобільних десантних військ;

- прищеплення курсантам корпоративної культури військовослужбовців, засвоєння традицій Високомобільних десантних військ тощо. 
Для того щоб позитивно впливати на становлення особистості та формування професійної компетенції курсантів, офіцер-наставник, на нашу думку, повинен мати певні професійні та особистісні якості:

- добре володіти знаннями з виховної роботи та мати відповідні вміння;

- володіти сучасними методами навчання та виховання;

- бути об'єктивним та справедливим;

- мати широкий світогляд, добре розвинені комунікативні та організаторські навички, витримку;

- бути патріотом своєї країни, зразком моральності та культури для курсантів;

- мати практичний досвід виконання військового обов'язку, щоб бути для курсантів взірцем тощо.

Окрім того, враховуючи реалії сьогодення, офіцер-наставник повинен бути готовим до міжнаціонального спілкування. Тому важливою вимогою $є$ гуманізм, повага до особистості майбутнього офіцера Високомобільних десантних військ.

Задля впливу на курсантів, на наш погляд, офіцер-наставник може використовувати такі засоби:

- актуалізацію мотивації досягнення успіху;

- створення ситуації успіху;

- заохочення;

- забезпечення курсантів інформацією про видатних десантників;

- спеціально організовані події, з вираженим позитивним емоційним чинником;

- власний приклад тощо.

Узагальнюючи все зазначене вище, можемо сформулювати таке визначення: педагогічне наставництво у військовому ВН3 - це система професійної діяльності офіцерів-наставників, спрямована на створення відповідних умов для успішного професійно-особистісного розвитку майбутнього офіцера.

Здійснений теоретичний аналіз дозволяє стверджувати, що педагогічне наставництво $є$ дуже важливим у військових ВНЗ, а офіцер-наставник безпосередньо впливає на формування особистісних і професійних якостей майбутніх офіцерів Високомобільних десантних військ.

У подальшому плануємо розробити програму роботи офіцера-наставника 3 курсантами ВДВ, яка сприятиме ефективному формуванню їхньої професійної компетентності.

1. Гришаев О. В. Записная книжка куратора студенческой группы: методические рекомендации по организации воспитательной деятельности куратора / О. В. Гришаев, М. В. Щербакова. - Воронеж : Изд-во Воронежского гос. ун-та, 2009. 134 c. 2. Демочкин С. В.Социально-педагогическое сопровождение профессионального становления курсантов военного вуза: автореф. дис. на соискание ученой степени канд. пед. наук / Демочкин Сергей Васильевич. - Ярославль, 2011 20 с. 3. Зеленская Н. В. Педагогическая концепция управления качеством подготовки офицерских кадров: дис. ... д-ра пед. наук / Зеленская Неля Васильевна. - СПб, 2008. - 424 с. 4. Коровин В. М. Система профессионального становления офицеров в военных вузах: [монография] / В. М. Коровин. - Воронеж: ВГУ, 2002. - 364 с. 5. Товт С. С. Социально-педагогическое обеспечение профессионального становления курсантов военного вуза: дис. ... канд. пед. наук/ Товт Сергей Степанович. - Кострома, 2009. - 169 с. 